Growth in mammals encompasses several stages, from intrauterine growth through infancy and childhood to adolescence. Each of these phases is characterized by very specific nutritional, molecular and endocrine perspectives which, under ideal conditions, allow the organism to achieve its genetically programmed growth patterns.

In this book, an international panel of experts addresses these topics in a historical, physiological and social perspective. The first part investigates the genetic, epigenetic, molecular and nutritional determinants of intrauterine and postnatal growth. Part two deals with non-evolutionary changes which occurred in the recent past, such as changes in body size in utero, during infancy and childhood, and during adolescence, and the potentially unfavorable consequences of enhanced nutrition and growth, including early onset of puberty, development of obesity, and increases in metabolic and cardiovascular disease. The last part addresses the question of which factors define healthy growth in light of the influence of nutritional, molecular and endocrine influences. Although the association between rapid changes in body size and adverse health effects is clear, the precise nature of causality remains uncertain.

Presenting the latest scientific findings in growth research, this publication provides essential reading for pediatricians, clinical investigators and health workers.

Nestlé Nutrition Institute Workshop Series, Vol. 71

Recent Advances in Growth Research:

Nutritional, Molecular

and Endocrine Perspectives

Editors: Gillman, M.W. (Boston, Mass.);

Gluckman, P.D. (Auckland);

Rosenfeld, R.G. (Los Altos, Calif.)

XVIII + 228 p., 33 fig., 14 tab., 2013

CHF 50.- / EUR 42.- / USD 59.00 (hard cover)

CHF 60.- / EUR 50.- / USD 71.00 (online)

Online versions are designed for

institutional purchase

Prices subject to change

EUR price for Germany, USD price for USA only

ISBN 978-3-318-02269-8 (hard cover)

e-ISBN 978-3-318-02270-4

Fields of Interest: Nutrition; Pediatrics;

Endocrinology; Molecular Biology; Genetics,

Social Medicine

\section{www.karger.com/nniws}

\section{KARGER}

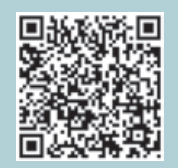

The experts' view

Nestlé Nutrition Institute Workshop Series, Vol. 71

\title{
Recent Advances in Growth
}

Research: Nutritional, Molecular

and Endocrine Perspectives

Editors

\section{Matthew W. Gillman \\ Peter D. Gluckman \\ Ron G. Rosenfeld}

\section{Contents}

Preface

Foreword

Contributors

\section{Drivers of Growth}

\section{Early Influences of Nutrition on Fetal Growth: \\ Makrides, M.; Anderson, A.; Gibson, R.A. \\ Early Influences of Nutrition on Postnatal Growth: Koletzko, B.; Beyer, J.; Brands, B.; \\ Demmelmair, H.; Grote, V.; Haile, G.; \\ Gruszfeld, D.; Rzehak, P.; Socha, P.; Weber, M.; \\ for The European Childhood Obesity Trial Study Group}

Genome-Wide Association Studies of Human

Growth Traits: Weedon, M.N.

Discussion on Nutrition and Genetics: Clark, A.J.L.

IGF-I in Human Growth: Lessons from Defects in the GH-IGF-I Axis: Hwa, V.; Fang, P.;

Derr, M.A.; Fiegerlova, E.; Rosenfeld, R.G.

Non-Imprinted Epigenetics in Fetal and Postnatal Development and Growth:

Godfrey, K.M.; Lillycrop, K.A.; Burdge, G.C.; Gluckman, P.D.; Hanson, M.A.

Epigenetic Anomalies in Childhood Growth Disorders: Netchine, I.; Rossignol, S.; Azzi, S.; Le Bouc, $Y$.

Early Growth and Development of Later Life Metabolic Disorders: Foo, J.-P.; Mantzoros, C.

Summary on Drivers of Growth: Gluckman, P.D.

\section{Secular Trends in Growth}

Human Growth: Evolutionary and Life History Perspectives: Gluckman, P.D.; Beedle, A.S.; Hanson, M.A.; Low, F.M.

Secular Trends in Birthweight: Oken, E.

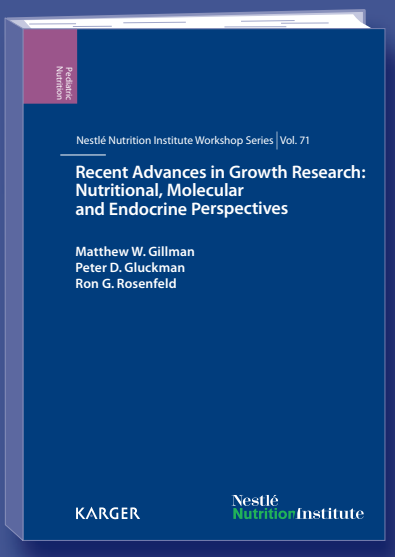

Secular Changes in Childhood, Adolescent and Adult Stature: Bogin, $B$.

Discussion on Human Biology in Motion: Ellison, P.T.

Economic Drivers and Consequences of Stunting: Alderman, $H$.

Discussion on Economic Drivers and Consequences of Stunting: Adair, L.S.

Epidemiologic Transitions: Migration and Development of Obesity and Cardiometabolic Disease in the Developing World: Forrester, $T$.

Discussion on Migration and Development of Obesity and Cardiometabolic Disease in the Developing World: Adair, L.S.

What Is Healthy Growth?

State of the Art of Growth Standards

Weaver, L.T.

Healthy Infant Growth: What Are the Trade-Offs in the Developed World? Belfort, M.B.; Gillman, M.W.

Discussion on Growth Standards and TradeOffs in Healthy Infant Growth: Law, $C$.

Relationship between Childhood Growth and Later Outcomes: Ferraro, A.A.;

Bechere Fernandes, M.T.

Public Policy Implications of Promoting Growth: Wise, P.H.

Pharmacological Interventions for Short Stature: Pros and Cons: Rosenfeld, R.G.

Discussion on Childhood Growth and Later Outcomes, Policy Implications and Treatment of Short Stature: Stein, A.D.

Concluding Remarks 


\section{Order Form}

\section{Nestlé Nutrition Institute Workshop Series}

Nestlé Nutrition Institute Workshop Series

Please send

copy/ies: Vol. 71: Recent Advances in Growth Research: Nutritional, Molecular and Endocrine Perspectives

CHF 50.- / EUR 42.- / USD 59.00

ISBN 978-3-318-02269-8 (hard cover)

_ copy/ies

In 2011, the two book series ,Nestlé Nutrition Workshop Series: Pediatric Program' and 'Nestlé Nutrition Workshop Series: Clinical \& Performance Program' have been merged to form the 'Nestlé Nutrition Institute Workshop Series'. One of the major components of this series is the organization of workshops and the publication of the proceedings. Each workshop focuses on the latest findings, the controversies and further research needs concerning various topics in nutrition.

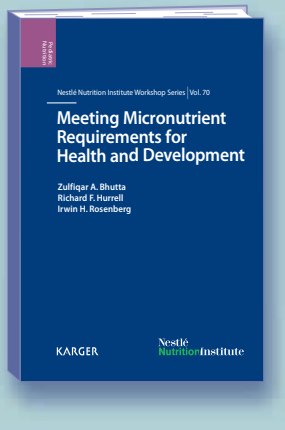

Vol. 70

Meeting Micronutrient Requirements for Health and Development

Editors: Bhutta, Z.A. (Karachi); Hurrell, R.F. (Zurich);

Rosenberg I.W. (Boston, Mass.)

XVIII + 194 p., 24 fig., 16 tab., 2012

CHF 50.- / EUR 42.- / USD 59.00 (hard cover)

CHF 60.- / EUR 50.- / USD 71.00 (online)

ISBN 978-3-318-02111-0 (hard cover)

e-ISBN 978-3-318-02112-7
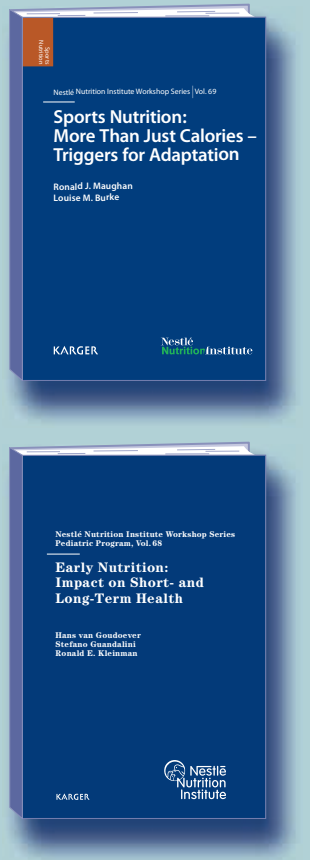

Vol. 69

Sports Nutrition: More than Just Calories -

Triggers for Adaptation

Editors: Maughan, R.J. (Loughborough); Burke, L.M. (Bruce)

XIV + 154 p., 14 fig., 2 tab., 2011

CHF 50.- / EUR 42.- / USD 59.00 (hard cover)

CHF 60.- / EUR 50.- / USD 71.00 (online)

ISBN 978-3-8055-9697-8 (hard cover)

e-ISBN 978-3-8055-9698-5

\section{Vol. 68}

Early Nutrition: Impact on Short and Long-Term Health

Editors: van Goudoever, H. (Amsterdam);

Guandalini, S (Chicago, Ill.); Kleinman, R.E. (Boston, Mass.)

XIV + 262 p., 25 fig., 15 tab., 2011

CHF 50.- / EUR 42.- / USD 59.00 (hard cover)

CHF 60.- / EUR 50.- / USD 71.00 (online)

ISBN 978-3-8055-9745-6 (hard cover)

e-ISBN 978-3-8055-9746-3

Online versions are designed for institutional purchase

Prices subject to change

EUR price for Germany, USD price for USA only

\section{ISBN 978-3-318-}

The book series Nestlé Nutrition Workshop Series on continuation beginning with vol.

Information on vols.

All Karger series are available on continuation. Each new volume will be sent upon publication until order is countermanded.

Postage and handling free with prepayment

For easy ordering or information

about other Karger publications log on to: www.karger.com

Payment

$\bigcirc$ Check enclosed $\bigcirc$ Please bill me

$\bigcirc$ Please charge to my credit card

$\bigcirc$ American Express $\bigcirc$ Diners

MasterCard $\bigcirc$ visa

Card No.

Exp. date:

Name/Address:

Date:

Signature:

Orders can be placed at agencies, bookstores, directly

S. Karger AG, P.O. Box, 4009 Basel (Switzerland)

Fax +41 6130612 34, E-Mail orders@karger.com

USA: S. Karger Publishers, Inc., 26 West Avon Road,

P.O. Box 529, Unionville, CT 06085 (USA),

Toll free: +1-800-828-5479

Germany: S. Karger GmbH, 79095 Freiburg

France: Librairie Médi-Sciences, 75007 Paris

Japan: Karger Japan, Inc., Tokyo 105-0012

South East Asia, China and Taiwan:

Karger Regional Office, Kuala Lumpur 50470 (Malaysia)

For details and further representatives

and agencies see www.karger.com/worldwide with the publisher, or with any Karger distributor.

\section{www.karger.com/nniws}

\section{KARGER}

To be ordered through: 